\title{
Iron deficiency in regular blood donors in Enugu (Southeastern Nigeria)
}

\author{
Grace Ifeoma Amilo, Martin Ossy Ifeanyichukwu, \\ Amauche Martina Ngwu, Godwin Okorie Obi
}

\begin{abstract}
Aims: Regular donors are often given some sort of non-monetary recognition. In Nigeria, about 92.9\% of individuals donate blood because of the benefits they get from hospital. The aim was to study iron status of regular blood donors who had donated at least one or two units of blood in their life. Methods: The study was prospectively conducted on 290 regular blood donors. The blood donors were divided into four groups, according to the number of units of blood they had given. Results: The difference in serum ferritin concentration of first group $(208.35 \pm 60.62 \mathrm{ng} / \mathrm{mL})$ was statistically significant $(p<0.05)$ compared with donors in third group $(34.20 \pm 21.89 \mathrm{ng} / \mathrm{mL})$ and fourth group (2.05 $\pm 0.22 \mathrm{ng} / \mathrm{mL})$. None of the first group donors suffered from iron deficiency, whereas $11 \%$ of the donors who had donated between 1115 units of blood within a 4-year period had iron deficiency. Conclusion: The results of this study
\end{abstract}

Grace Ifeoma Amilo1, Martin Ossy Ifeanyichukwu², Amauche Martina $\mathrm{Ngwu}^{3}$, Godwin Okorie $\mathrm{Obi}^{4}$

Affiliations: ${ }^{1} \mathrm{PhD}$, Senior Lecturer, Medical Laboratory Science, Nnamdi Azikiwe University, Nnewi Campus, Anambra State, Nigeria; ${ }^{2} \mathrm{PhD}$, Head of Department, Medical Laboratory Science, Nnamdi Azikiwe University, Nnewi Campus, Anambra State, Nigeria; ${ }^{3}$ Bachalor of Medical Laboratory Science, Medical Laboratory Scientist 1, Hematology and Immunology, Enugu State University of Science and Technology, Enugu, Enugu State, Nigeria; ${ }^{4}$ Associate Professor of Hematology, FMCpath, Head of Department, Hematology and Immunology, Enugu State University of Science and Technology, Enugu, Enugu State, Nigeria.

Corresponding Author: Martin Ositadinma Ifeanyichukwu, Nnewi, Anambra State, Nigeria. PMB 5001; Ph: +234 08037200407; Email: moifeanyi@yahoo.co.uk

Received: 24 March 2014

Accepted: 28 April 2014

Published: 31 July 2014 reveal the presence of iron deficiency in second group, third group and fourth group.

Keywords: Blood donors, Iron deficiency, Ferritin, Mean corpuscular volume (MCU)

\section{How to cite this article}

Amilo GI, Ifeanyichukwu MO, Ngwu AM, Obi GO. Iron deficiency in regular blood donors in Enugu (Southeastern Nigeria). Int $\mathrm{J}$ Blood Transfus Immunohematol 2014;4:1-6.

Article ID: 100013IJBTIGA2014

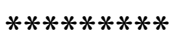

doi:10.5348/ijbti-2014-13-OA-1

\section{INTRODUCTION}

Blood donation results in a substantial (200-250 mg) loss of iron at each collection procedure, during which up to 425-475 $\mathrm{mL}$ of whole blood are withdrawn and subsequent mobilization of iron from body stores [1]. Chronic iron deficiency is a well-recognized complication of regular blood donation. A healthy individual can donate blood up to four times a year, i.e., at three months intervals as iron stores can be depleted if blood is donated more frequently [2]. In developing countries such as Nigeria, established blood supplies are limited and donors usually give blood when family or friends need a transfusion. About $92.9 \%$ of blood donors in Southeastern Nigeria receive incentives such as assurance that donors would have priority during shortages, free antenatal registration, free T-shirts, umbrellas, pens, towels, one bottle of malt, two raps of MoiMoi, excise books and face caps immediately after blood donation. This method of blood donation is being practiced only in government hospital 
blood banks [3, 4]. Two of incentives such as assurance of blood donors having priority during shortage and free antenatal registration made most donors to donate whenever they are due, i.e, at intervals of three months. This act of given incentives after blood donation in this part of the country has made our blood donation practices not to meet up with the World Health Organization set goal in 1997 which demand that all blood donations should come from unpaid volunteer donors [5]. This study was, therefore, conducted to investigate the iron status of regular blood donors in blood bank laboratory of Enugu State University of Science and Technology Teaching Hospital Enugu (ESUTTH), Nigeria based on the number of units of blood each donor had donated.

\section{MATERIALS AND METHODS}

Subjects: Two hundred and ninety regular blood donors aged between 18-50 years that donated blood in blood bank laboratory ESUTTH, Nigeria were recruited into the study after given informed consent. A total of 290 blood donors were included in this study in which 223 were males and 67 were females. All donors were screened using a HemoCueHb 301. Only donors whose hemoglobin was between $12.0 \mathrm{~g} / \mathrm{dL}$ and $13.0 \mathrm{~g} / \mathrm{dL}$ were eligible for the study. Each donor donated $450 \mathrm{~mL}$ of whole blood. Questionnaire classification of the donors into groups was applied. Regular blood donors in this work were defined as bloods donors that receive nonmonetary remuneration after donation. In this study, iron stores were considered depleted when serum ferritin values were less than $12 \mathrm{ng} / \mathrm{mL}$, and reduced when the values were between $13^{-20} \mathrm{ng} / \mathrm{mL}$. Iron deficiency was considered present when the serum ferritin was less than $12 \mathrm{ng} / \mathrm{mL}$ and transferrin saturation percentage less than 15 [6].

Study population: Enugu State is in the Southeast geographical zone of Nigeria. According to the 2006 Nigerian census, the Enugu metropolitan area has an estimated population of 722,664.

Methods: Serum iron and total iron binding capacity (TIBC) were estimated using a ferrozine-based iron/TIBC reagent set (TECO DIAGNOSTICS, USA). Test procedures were conducted as described in the manufacturer's standard operating manual included with the kit. Transferrin saturation percentage was calculated from the serum iron concentration and TIBC values as follows: transferrin saturation percentage is equal to serum iron/TIBCx10o [6]. Serum ferritin was measured using a human ferritin enzyme immunoassay kit (BIOCHECK, INC, 323 Vintage Park Dr. Foster City, CA 94404). The ferritin quantitative test is based on a solid phase enzyme-linked immunosorbent assay (ELISA). The procedure was as described by the manufacturer of the human ferritin enzyme immunoassay kit. Twenty microliters of standard, specimens and controls were added into wells of microtiter plate. Hundred microliters of enzyme conjugate reagent was dispensed into each well. Gently mixed for 30 seconds and incubated at room temperature for 45 minutes. The incubated mixture was removed by flicking the plate contents into sink. The microtiter wells were rinsed and flicked five times with deionized water. Hundred microliters of TMB reagent was added into each well and gently mixed for 10 seconds. Then the mixture was incubated at room temperature in the dark for 20 minutes. The reaction was stopped with addition of stop solution to each well which changed all the blue color to yellow. Absorbance was read at 450 $\mathrm{nm}$ with a microtiter plate reader within 15 minutes. Hemoglobin results were determined photometrically using the HemoCue meter (Hb 301). Packed cell volume (PCV) was determined using a microhematocrit centrifuge (DIN58933 of Germany). Mean corpuscular hemoglobin concentration (MCHC) was also calculated.

Statistics: The group comparisons were determined by one-way analysis of variance (ANOVA). Comparison between mean values of iron parameters were compared with student's t-test and 95\% confidence interval were also applied. A 'p' value less than 0.05 was considered statistically significant.

\section{RESULTS}

A total of 290 regular blood donors were included in this study. Only donors with hemoglobin levels of $\geq 12$. $\mathrm{g} / \mathrm{dL}$ for female and $\geq 13.0 \mathrm{~g} / \mathrm{dL}$ for male were eligible for the study. The blood donors were grouped according to the number of units of blood they had given since they started donating blood. The first group $(n=40)$ were apparently healthy adult male and female Enugu state indigenes with no previous history of blood donation. Donors in second group $(n=211)$ had given between 1-5 units of blood within two years. Third group donors $(n=30)$ had donated between $6-10$ units of blood within three years. Fourth group $(n=9)$ had donated between 11-15 units of blood within four years. Ferritin, serum iron concentration, TIBC and transferrin saturation percentage were evaluated in all four groups of blood donors. In first group, the mean serum iron concentration was $43.10 \mu \mathrm{mol} / \mathrm{L}(\mathrm{SD}=2.27$ ) with $95 \% \mathrm{CI}$ of $43.10 \pm 0.70$. In second group, it was $26.25 \mu \mathrm{mol} / \mathrm{L}(\mathrm{SD}=3.57)$ with $95 \%$ CI of $26.25 \pm 0.48$. In third and fourth group, the mean serum iron concentration were $34.20 \mu \mathrm{mol} / \mathrm{L}$ (SD $=21.20$ ) with $95 \% \mathrm{CI}$ of $34.20 \pm 8.15$ and $10.35 \mu \mathrm{mol} / \mathrm{L}$ $(\mathrm{SD}=0.67)$ with $95 \% \mathrm{CI}$ of $10.35 \pm 2.26$, respectively (Table 1) (Figure 1). The mean serum iron concentration was significantly higher in first group donors, who had no previous history of blood donation, than in donors in second, third and fourth group. The total iron binding capacity of donors in first group was significantly lower than those donors in second and fourth group. The percentage transferrin saturation of donors in first group was significantly higher than those donors in second, third and fourth group. 
The mean ferritin concentration in first group donors $208.35 \mathrm{ng} / \mathrm{mL}(\mathrm{SD}=60.62)$; $95 \%$ CI of $208.35 \pm 18.79$, was higher than that in donors in second, third and fourth groups: $63.05 \mathrm{ng} / \mathrm{mL}(\mathrm{SD}=23.48)$; $95 \% \mathrm{CI}$ of $63.05 \pm 3.17$, $34.20 \mathrm{ng} / \mathrm{mL}(\mathrm{SD}=21.89) ; 95 \%$ CI of $34 \pm 8.15$ and 2.05 $\mathrm{ng} / \mathrm{mL}(\mathrm{SD}=0.22) ; 95 \% \mathrm{CI}$ of $2.05 \pm 0.17$, respectively (Table 1) (Figure 2). On comparing, the concentration of serum ferritin in first group with third group and fourth group, it was seen that ferritin levels decreased with increasing number of donation (Table 1). The serum ferritin concentration was statistically significantly different when comparing donors in third and fourth groups with first group.
Iron stores were reduced in $1.4 \%(3 / 211)$ in donors that donated $1-5$ units of blood (second group), whereas $6.7 \%$ of third group donors who had donated between $6-10$ units of blood had reduced iron stores (Table 2). None of the first group donors suffered from iron deficiency, while 4 out of 211 (1.9\%), 1 out of 30 (3.3\%) and 1 out 9 (11\%) of donors who had donated 1-5 units, 6-10 units and 11-15 units of blood within two years, three and four years, respectively had ferritin concentrations below 12 $\mathrm{ng} / \mathrm{mL}$ and percentage transferrin saturation below 15 . There was no significant difference between hemoglobin, $\mathrm{PCV}$, Mean corpuscular volume (MCV) and increasing instances of donation $(\mathrm{p}<0.05)$ (Table 1).

Table 1: Mean values of iron, total iron binding capacity, percentage transferring saturation and ferritin concentration, hemoglobin, packed cell volume and mean corpuscular hemoglobin concentration in donors grouped according to frequency of donation.

\begin{tabular}{|c|c|c|c|c|c|c|c|c|c|c|c|}
\hline Groups & $\begin{array}{l}\text { Number } \\
\text { of } \\
\text { donation }\end{array}$ & $\begin{array}{c}\text { Serum } \\
\text { iron } \\
(\mu \mathrm{mol} / \mathrm{L})\end{array}$ & $\begin{array}{c}\text { TIBC } \\
(\mu \mathrm{mol} / \mathrm{L})\end{array}$ & $\begin{array}{c}\text { Transferrin } \\
\text { saturation } \\
\text { (\%) }\end{array}$ & $\mathrm{Hb}(\mathrm{g} / \mathrm{dL})$ & PCV (\%) & $\begin{array}{l}\operatorname{MCHC}(\mathrm{g} / \\
\mathrm{dL})\end{array}$ & $\begin{array}{c}\text { Ferritin (ng/ } \\
\text { mL) }\end{array}$ & $\begin{array}{c}\text { Median } \\
\text { age of } \\
\text { male }\end{array}$ & $\begin{array}{l}\text { No. } \\
\text { of } \\
\text { M }\end{array}$ & $\begin{array}{l}\% \text { of } \\
\text { male }\end{array}$ \\
\hline 1st group & o & $43.10 \pm 2.27$ & $73.05 \pm 10.30$ & $29.85 \pm 11.59$ & $14.58 \pm 1.24$ & $43.73 \pm 3.73$ & $33.33 \pm 0.50$ & $208.35 \pm 60.62$ & 23.50 & 19 & 47.50 \\
\hline 2nd group & $1-5$ & $26.25 \pm 3.57$ & $77.50 \pm 12.50$ & $15.90 \pm 3.06$ & $14.45 \pm 2.36$ & $42.44 \pm 5.48$ & $33.34 \pm 0.03$ & $63.05 \pm 23.48$ & 27.50 & 165 & 78.20 \\
\hline 3rd group & $6-10$ & $34.20 \pm 21.89$ & $76.20 \pm 0.62$ & $10.80 \pm 5.49$ & $14.48 \pm 1.31$ & $40.78 \pm 6.23$ & $33.32 \pm 0.02$ & $34.20 \pm 21.89$ & 25.50 & 30 & 100 \\
\hline 4th group & $11-15$ & $10.35 \pm 0.67$ & $82.50 \pm 7.90$ & $13.25 \pm 0.44$ & $14.89 \pm 0.52$ & $44.66 \pm 1.57$ & $33.33 \pm 0.50$ & $2.05 \pm 0.22$ & 27.50 & 9 & 100 \\
\hline $\begin{array}{l}\text { 1st:2nd } \\
\text { group }\end{array}$ & $0: 1-5$ & $0.00^{*}$ & $0.01^{*}$ & $0.00^{*}$ & 1.00 & 0.82 & 0.82 & $0.00^{*}$ & & & \\
\hline $\begin{array}{l}\text { 1st:3rd } \\
\text { group }\end{array}$ & $0: 6-10$ & $0.00^{*}$ & 0.44 & $0.00^{*}$ & 1.00 & 0.29 & 0.98 & $0.00^{*}$ & & & \\
\hline $\begin{array}{l}\text { 1st:4th } \\
\text { group }\end{array}$ & $0: 11-15$ & $0.00^{*}$ & $0.00^{*}$ & $0.00^{*}$ & 0.74 & 0.74 & 1.00 & $0.00^{*}$ & & & \\
\hline
\end{tabular}

\section{Abbreviations}

TIBC: Total iron binding capacity, Hb: Hemoglobin, PCV: Packed cell volume, MCHC: Mean corpuscular hemoglobin concentration No. of M: Number of male gender, \% of male: Percentage of male gender

Table 2: Showed distribution of population under study according to iron status and frequency of donation

\begin{tabular}{|c|c|c|c|c|c|}
\hline Groups & $\begin{array}{l}\text { number of } \\
\text { donation }\end{array}$ & $\begin{array}{l}\text { number of } \\
\text { donors }\end{array}$ & $\begin{array}{c}\text { reduced iron stores } \\
\text { (ferritin }=13-20 \mathrm{ng} / \mathrm{mL} \text { ) }\end{array}$ & $\begin{array}{l}\text { depleted iron (ferritin } \\
\quad=10-12 \mathrm{ng} / \mathrm{mL} \text { ) }\end{array}$ & $\begin{array}{c}\text { Iron deficiency } \\
\text { (ferritin<12ng/mL + } \\
\text { \%transferrin < 15) }\end{array}$ \\
\hline 1st group & o & 40 & & & \\
\hline 2nd group & $1-5$ & 211 & $1.4 \%(n=3)$ & $0.95 \%(n=2)$ & $1.9 \%(n=4)$ \\
\hline 3rd group & $6-10$ & 30 & $6.7 \%(n=2)$ & $0 \%(n=0)$ & $3 \cdot 3 \%(n=1)$ \\
\hline 4th group & $11-15$ & 9 & $0 \%(n=0)$ & $0 \%(n=0)$ & $11 \%(\mathrm{n}=1)$ \\
\hline
\end{tabular}




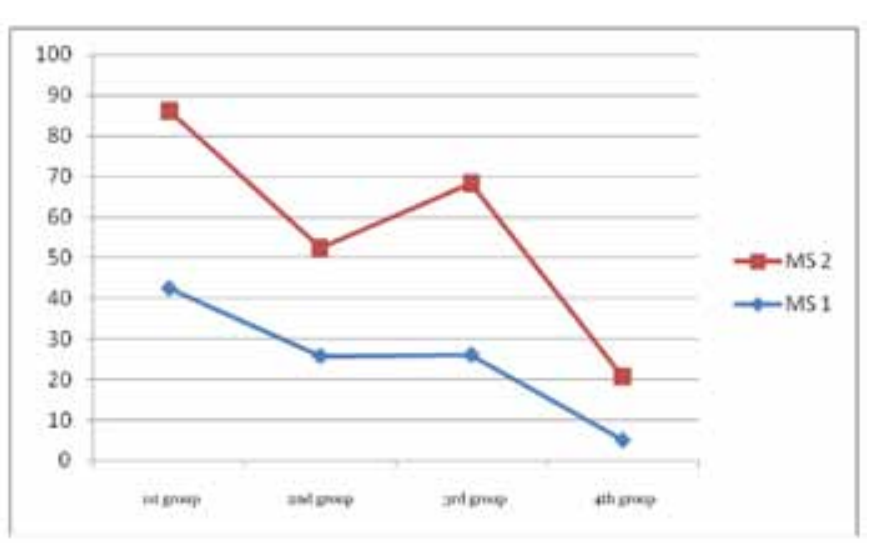

Figure 1: Mean serum iron values of 1st group to 4 th group with 95\% CI.

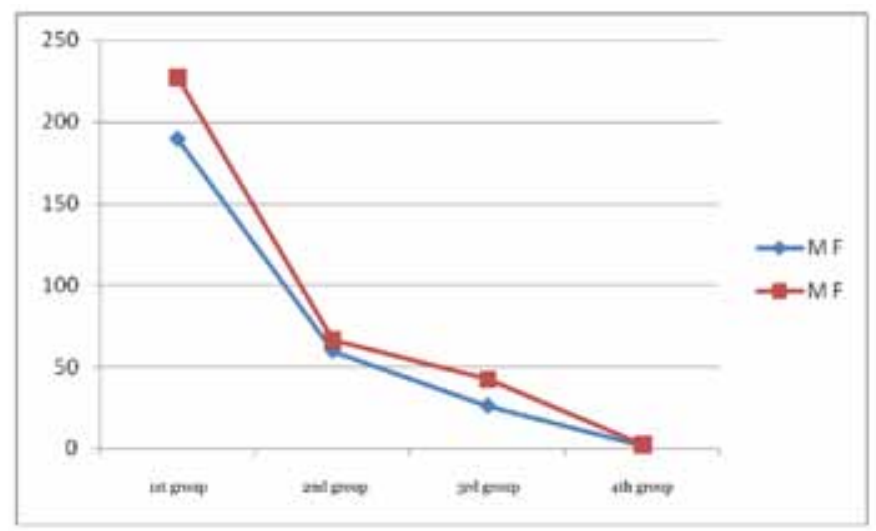

Figure 2: Mean ferritin values of 1st group to 4 th group with 95\% CI.

\section{DISCUSSION}

In this study, $1.9 \%, 3.3 \%$ and $11 \%$ of regular blood donors in Enugu developed iron deficiency at interval of two years, three years and four years, respectively and defined as ferritin concentration $<12 \mathrm{ng} / \mathrm{mL}$ and TS (Transferrin saturation) $<15$. In comparison with study from Iran which reported iron deficiency in $28 \%$ male donors who donated their blood about five to ten times in previous three years, our obtained figures are lower in the present study [1]. The reason behind our lower figure may be because of government effort to reduce poverty in Nigeria which now made our youth to have access to good medical care. Iron depletion was seen among 0.95\% of regular blood donors that have donated 1-5 units of blood in two years. In comparable with study done in Poland that reported iron depletion of $49.7 \%$ in 10 instances of donation [7], our result had a lower figure. This lower figure in our study may be due to attitude of people to blood donation, i.e., they donate mainly when the recipient is their friend or relation. Reduced iron store was seen in $1.4 \%$ of donors that donated $1-5$ units of blood in two years and $6.7 \%$ of donors that donated 6-10 units of blood in three years. In comparable with study done in Iran that reported lack of iron stores in $4.66 \%$ of regular donors [8]. Our results have a higher figure than their result. This study has shown inverse relationship of serum iron, ferritin and transferrin saturation with increasing number of units of blood donated. Significant reduction in the levels of these three parameters was observed in the donors that have donated 11-15 units of blood. In the present study, the hemoglobin results among none donors 1st group, 2nd group, 3rd group, and 4th group were $14.58 \pm 1.24,14.45 \pm 2.36,14.48 \pm 1.31$ and $14.89 \pm 0.52$, respectively. In comparison with study done in Malaysia which their hemoglobin results were $15.56 \pm 1.48,15.12 \pm 1.44$ and $14.95 \pm 1.08$, respectively our results are slightly lower than these results [9].

\section{CONCLUSION}

This study showed that blood donors in Enugu metropolis develop iron deficiency irrespective of the number of units of blood they had given out. Based on these findings, it is suggested that ferritin test should be included in pre-screening test before blood donation in Nigeria.

\section{$* * * * * * * * *$}

\section{Acknowledgements}

The authors thank the donors, who participated in the study and Ukamaka Maureen Onyia of the National Blood Transfusion Centre Enugu for her technical assistance.

\section{Author Contributions}

Grace Ifeoma Amilo - Drafting the article, Critical revision of the article, Final approval of the version to be published

Martin Ossy Ifeanyichukwu - Drafting the article, Critical revision of the article, Final approval of the version to be published

Amauche Martina Ngwu - Conception and design, Acquisition of data, Analysis and interpretation of data, Drafting the article, Critical revision of the article, Final approval of the version to be published

Godwin Okorie Obi - Drafting the article, Critical revision of the article, Final approval of the version to be published

\section{Guarantor}

The corresponding author is the guarantor of submission.

\section{Conflict of Interest}

Authors declare no conflict of interest.

\section{Copyright}

(C) 2014 Grace Ifeoma Amilo et al. This article is distributed under the terms of Creative Commons Attribution License which permits unrestricted use, distribution and reproduction in any medium provided the original author(s) and original publisher are properly credited. 
Please see the copyright policy on the journal website for more information.

\section{REFERENCES}

1. Javadzadeh Shahshahani H, Attar M, Taher Yavari M. A study of the prevalence of iron deficiency and its related factors in blood donors of Yazd, Iran 2003. Transfus Med 2005;15(4):287-93.

2. Popovsky MA. Anemia, iron depletion, and the blood donor: It's time to work on the donor's behalf. Transfusion 2012;52(4):688-92.

3. Schmunis GA, Cruz JR. Safety of the Blood Supply in Latin America. Clinical Microbiology Reviews 2005:18(1):12-29.

4. Wales PW, Lau W, Kim PC. Directed blood donation in pediatric general surgery: Is it worth it? J Pediatr Surg 2001;36(5):722-5.
5. Brown T. Strengthening Blood Systems In Africa: Progress Under PEPFAR and Remaining Challenges. AABB News 1998:30.

6. Jeremiah ZA, Koate BB. Reference percentiles of hematological and biochemical iron values of blood donors in Portharcourt Nigeria. Hematology 2009;14(6):366-70.

7. Szymczyk-Nuzka M, Wolowiec D. Iron stores in regular blood donors. Pol Arch Med Wewn 2003;110(6):1415-21. [Article in Polish].

8. Yousefinejad V, Darvishi N, Arabzadeh M, Soori M, Magsudlu M, Shafiayan M. The evaluation of iron deficiency and anemia in male blood donors with other related factors. Asian J Transfus Sci 2010 Jul;4(2):123-7.

9. Norashikin J, Roshan TM, Rosline H, Zaidah AW, Suhair AA, Rapiaah M. A study of serum ferritin levels among male blood donors in Hospital Universitisains Malaysia.Southeast Asian J Trop Med Public Health 2006;37(2):370-3.

\section{ABOUT THE AUTHORS}

Article citation: Amilo GI, Ifeanyichukwu MO, Ngwu AM, Obi GO. Iron deficiency in regular blood donors in Enugu (Southeastern Nigeria). Int J Blood Transfus Immunohematol 2014;4:1-6.

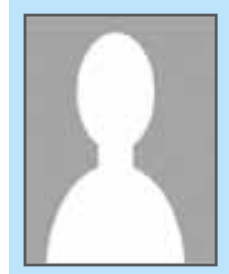

Grace Ifechukwudebelu Amilo is Sub Dean School of Post Graduate Studies and past Head of Department, Hematology Department, Faculty of Medicine, Nnamdi Azikiwe University, Awka, Nnewi Campus, Nigeria. She earned the undergraduate degree from Department of Medical Laboratory Science, State University of New York at Buffalo, New York. USA and postgraduate degree from from Medical Laboratory Science, Long Island University, Greenvale, Long Island New York, USA. Doctorate was earned in Nnamdi Azikiwe University Awka, Nigeria. The research work was on Immunology of Pulmonary Mycobacterium tuberculosis with or without HIV. She has Published 12 articles in national and14 articles in international journals. Her research interest is immunology of infectious diseases; HIV, PMT and malaria.

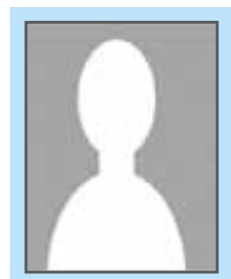

Martin Ositadinma Ifeanyichukwu is the current Head of Department at Department of Medical Laboratory Science, Faculty of Health Science and Technology, Nnamdi Azikiwe University, Awka, Nnewi Campus, Nigeria. He earned the undergraduate degree, Fellow of Medical Laboratory Council of Nigeria (FMLSCN) from University of Calabar, Nigeria, and postgraduate degree from (MSc.) from Department of Immunology, Faculty of Medicine Nnamdi Azikiwe University, Awka, Nigeria. He also earned Doctorate degree at Department of immunology Faculty of Medicine, Nnamdi AZikiwe University, Awka, Nigeria. Research was Immune responses in infected individuals pre- and postanti- retroviral therapy. He has published up to 52 research papers in both national and international academic journals. His research interest is immunology, haematology of HIV, tuberculosis, and malaria infections.

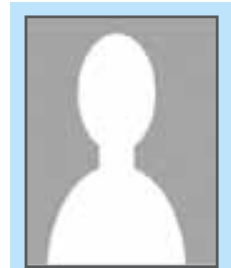

Ngwu Amauche Martina is Medical Laboratory Scientist 1 at Department of Hematology and Immunology, College of Medicine, Enugu State University of Science and Technology, Enugu, Nigeria. She earned the undergraduate degree BMLS from Department of Medical Laboratory Science, Ambrose Alli University, Ekpoma, Nigeria and She has just completed her MSc. from Department of Medical Laboratory Science, Nnamdi Azikiwe University, Awka, Nigeria. She has published one research paper in international academic journals. Her research interests include transfusion medicine and hemoglobinopathy. She intends to pursue $\mathrm{PhD}$ in hematology very soon. 
Obi Godwin Okorie is Head of Department at Hematology and Immunology, College of Medicine, Enugu State University of Science and Technology, Enugu, Nigeria. He earned the undergraduate degree MBBS from University of London, England and MRCP from Royal College of Physicians' of Edinburgh Scotland UK, DTM\&H from the University of Liverpool England UK, FMCPATH from National Postgraduate Medical College, NIGERIA. He has published 27 research papers in both national and international journals and also authored a book-Medicine and Law. His research interests include nutritional anemia, hemoglobinopathy and studies in tropical splenomegally syndrome.

Access full text article on other devices

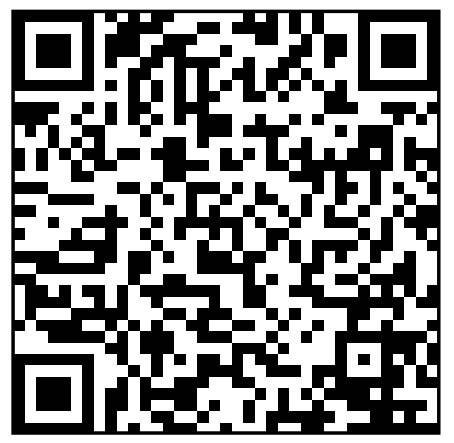

Access PDF of article on other devices

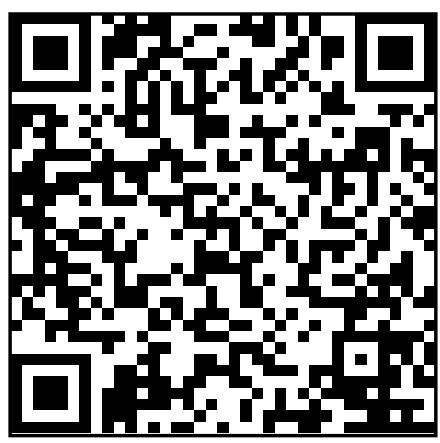

